\title{
ANALYSIS OF THE POSSIBILITY OF THE POLYMERIC AGGREGATES USE IN THE DESIGN OF BUILDING BLOCK
}

\author{
Rodríguez García José ${ }^{1}$, Armendáriz Mireles Eddie', López Ceballos Roque1, \\ Rocha Rangel Enrique ${ }^{1}$, López García Ricardo ${ }^{2}$, Jaime Hinojosa Torres ${ }^{3,}{ }^{凶}$
}

https://doi.org/10.23939/chcht14.01.116

\begin{abstract}
Particulate composite was prepared from a mixture of cement, gravel and water with additions of a polyepoxide and/or expanded polystyrene in powder. For consolidation, each mixture was poured into a mold, remaining for a short period and then removed. For complete solidification the specimens were cured with water during the final stage. The weight, compressive strength and thermal conductivity of the composite were determined.
\end{abstract}

Keywords: building block, particulate composite, compressive strength, thermal conductivity, thermally stable polymer.

\section{Introduction}

One of the elements of masonry used in the construction industry is the building block, because of its resistance to compression and durability. However, concrete block has limitations: it is relatively heavy and possesses a poor thermal insulation. Such features can give place to the collapse of the constructions during seismic events; likewise, the intramural conditions are out of the comfort zone in extreme climates [1-4]. The objective of this research is the improvement of the physical properties of concrete block by means of the addition of polyepoxide particles and/or expanded polystyrene particles, with the purpose of presenting a use option for this sort of industrial waste in the production of lightweight masonry elements, that are able to limit the transfer of heat and possess high resistance to compression[5-7]. The aggregates used are polymers, thermally stable, with physical properties [8] which will

\footnotetext{
${ }^{1}$ Victoria Polytechnic University, Department of Manufacture in Advanced Materials,

Ciudad Victoria, 87138 Tamaulipas, Mexico

${ }^{2}$ Victoria City Technological Institute, Department of Metal Mechanics, Ciudad Victoria, 87010 Tamaulipas, Mexico

${ }^{3}$ National Autonomous University of Mexico, Engineering Department, Cuautitlán Izcalli, 54714 Estado de México, Mexico

jaimeht@unam.mx

(c) Rodríguez G. J., Armendáriz M. E., López C. R., Rocha R. E., López G. R., Hinojosa T. J., 2020
}

allow producing the material in study with the cited qualities. With regard to the flammability of the utilized polymers it must be considered that these aggregates are encapsulated, practically; since the concrete contained in them is acting as a facing material, this allows avoiding the hazard when entering in contact with fire. It is necessary to remark that the polyepoxide that is used in this study is a cured epoxy resin, whereas the expanded polystyrene contains compounds that slow the fire risk. Therefore, it is possible to build the building blocks ensuring fire safety using polyepoxide and/or expanded polystyrene.

\section{Experimental}

\subsection{Materials}

The materials used in obtaining of the particulate composite (concrete block + polyepoxide particles, concrete block + expanded polystyrene) are stated as follows: Composed Portland cement of fast resistance CPC-30R with a relative density of $3.12 \mathrm{~g} / \mathrm{cm}^{3}$, specific surface of $4156 \mathrm{~cm}^{2} / \mathrm{g}$, fineness M-325 of $96.5 \%$, initial and final setting time of 158 and $310 \mathrm{~min}$ and chemical composition of $\mathrm{CaO}(65.1 \%), \mathrm{SiO}_{2}(20.2 \%), \mathrm{Al}_{2} \mathrm{O}_{3}$ (4.1\%), $\mathrm{SO}_{3}(3.5 \%), \mathrm{Fe}_{2} \mathrm{O}_{3}(3.4 \%), \mathrm{MgO}(1 \%)$ and others (2.7\%); gravel with the relative apparent density of $2.66 \mathrm{~g} / \mathrm{cm}^{3}$ and the fineness modulus of 3.5; polyepoxide particles as aggregate with a relative apparent density of $1.77 \mathrm{~g} / \mathrm{cm}^{3}$ (3 mm particle size); expanded polystyrene (EPS) as aggregate with the same preparation process ( $3 \mathrm{~mm}$ particle size); water free of salts.

\subsection{Methods}

The epoxy resin was analyzed in order to determine the feasibility of its usage as an aggregate. The result of the analysis showed that this polymer is chemically inert, noncorrosive, nonexplosive, nontoxic and nonflammable. In order to standardize the particle size a cutting mill IKA model MFLOBS1 was utilized; the milling process was 
carried out in agreement with the standard ASTM-C-33, by establishing the rotation speed of $4000 \mathrm{rpm}$. Gravel was sieved by employing meshes from 4 to $200(4.76 \mathrm{~mm}$ to $74 \mu \mathrm{m})$; the fineness modulus of 3.5 was determined.
To remove residual humidity, the sieved gravel was placed inside an electric furnace at $333 \mathrm{~K}$ for $24 \mathrm{~h}$. Groups of 11 types of mixtures were prepared; the mixture composition of each group is presented in Table 1.

Table 1

Composition of prepared mixtures

\begin{tabular}{|c|c|c|c|c|}
\hline \multirow{2}{*}{ Mixture } & \multicolumn{4}{|c|}{ Mixture composition, wt. \% } \\
\cline { 2 - 5 } & Cement & Gravel & Expanded polystyrene & Polyepoxide \\
\hline M1 & 10.64 & 89.36 & - & - \\
\hline M2 & 18.98 & 79.81 & 1.21 & - \\
\hline M3 & 31.32 & 65.82 & 2.86 & - \\
\hline M4 & 13.64 & 85.92 & 0.44 & 25.09 \\
\hline M5 & 14.43 & 60.48 & - & 45.98 \\
\hline M6 & 17.45 & 36.57 & - & 10.67 \\
\hline M7 & 12.27 & 77.06 & 2.27 & 62.04 \\
\hline M8 & 35.69 & - & 0.87 & 71.86 \\
\hline M9 & 27.27 & - & 4.66 & 44.33 \\
\hline M10 & 51.01 & - & - & 77.84 \\
\hline
\end{tabular}

Note: in all cases the amount of water was $59.1 \mathrm{ml} / \mathrm{kg}$

The mixtures were introduced into cylindrical containers; for the homogenization the containers were put on rotational rollers following the standard ASTM-C192. The homogenized mixtures were poured into cubic bronze molds $(5 \times 5 \times 5 \mathrm{~cm})$ without vibrating compaction and left for $24 \mathrm{~h}$ before being removed from molds. Ten particulate composites of each mixture were prepared and cured in water for 28 days at room temperature before being subject of study. The mixture M1 was considered as the control sample, with the purpose of having the reference values.

Measurements of the weight and density of the particulate composite specimen were carried out by utilizing a digital mass balance. Evaluation of the compressive strength was carried out in a hydraulic press FORNEY LT 900/920, according to the standard compression test ASTM-C-109. Eq. (1) [9].

The compressive strength was determined by using

$$
F^{\prime} c=P A^{-1}
$$

where $F^{\prime} c$ is the compressive strength of solid materials, $\mathrm{kg} / \mathrm{cm}^{2} ; P$ is the load applied to the sample in study, $\mathrm{kg} ; A$ is the cross-section, $\mathrm{cm}^{2}$.

The thermal conductivity $K$ of the particulate composite specimen was determined according to standard test method (ASTM-C-177) for heat flux in steady estate, by means of the guarded-hot-plate apparatus and referring to Fourier's law [8].

$$
Q / A=K(\Delta T / \Delta x)
$$

where $Q / A$ i s the heat flow per unit area, cal $\cdot \mathrm{s}^{-1} / \mathrm{cm}^{2} ; K$ is the coefficient of thermal conductivity, $\mathrm{cal} / \mathrm{cm} \cdot \mathrm{s} \cdot \mathrm{K} ; \Delta T / \Delta x$ is the temperature gradient over the thickness of the sample, $\mathrm{K} / \mathrm{cm}$.

\section{Results and Discussion}

\subsection{Physical Appearance}

An important aspect is the physical appearance of the obtained specimen, since the appearance is an important aspect to market the product. Fig. 1 shows the representative particulate composite specimens of 11 mixtures that were used in the study. It can be noted that some specimens are presenting an acceptable physical appearance (superficial texture), solidity and rigidity visible and without loss of material on the surface (samples M1, M5, M6, M7 and M11). The abovementioned is the result of having utilized polyepoxide particles, since these particles are very hard, rigid and dense. Furthermore, this type of polymer exhibits an excellent interaction with the other constituents of the mixture, by including the cement and water.

On the contrary, the samples with high percentage of expanded polystyrene, M2, M3, M8, and M10 have areas with high porosity and some parts are not uniform (blocks with unequal sides). This can be attributed to the physical characteristics of the expanded polystyrene (low values of hardness, strength, rigidity, and density) and poor interaction with cement and water, the same as with the polyepoxide. 


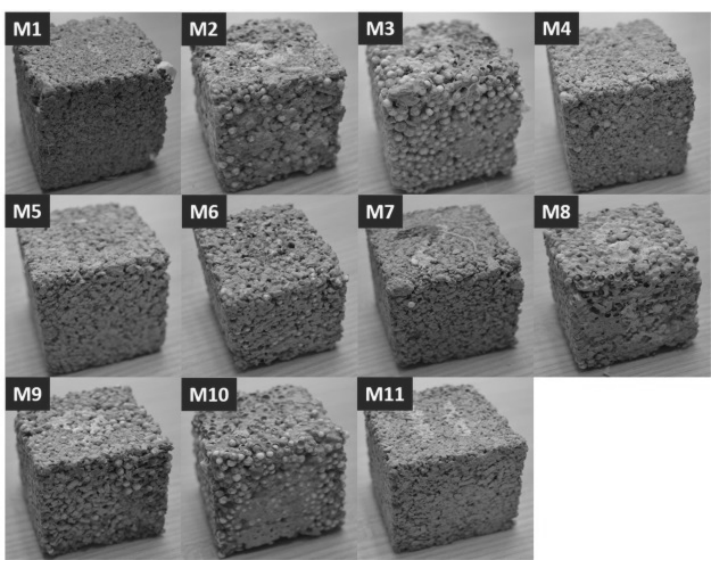

Fig. 1. Physical appearance of the particulate composite specimens of the utilized mixtures

\subsection{Weight and Density}

Fig. 2 shows the measurements of the average weight and density of the specimens for each mixture (shaded bars). It can be clearly seen that the density decreases when replacing the gravel by polymer particles and this decrease is directly proportional to the amount of polymer added. In particular, the specimens corresponding to mixture M10 attained the density average of $0.64 \mathrm{~g} / \mathrm{cm}^{3}$, which represents the reduction of $\sim 76 \%$ in density with respect to control sample M1 $\left(2.71 \mathrm{~g} / \mathrm{cm}^{3}\right)$, followed by the specimens prepared according to mixtures M3, M8 and M9 with the density reduction rates of $57.5,60.5$ and $48 \%$, respectively.

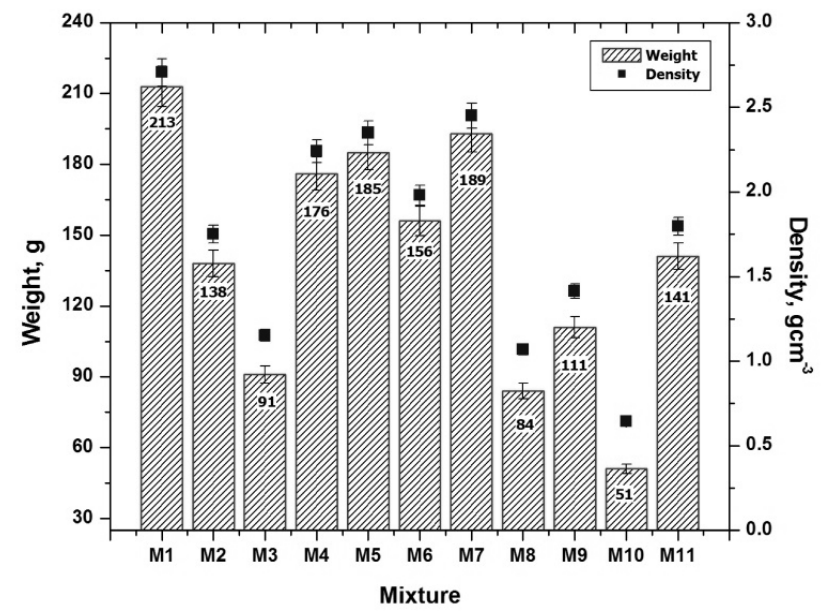

Fig. 2. Average values of the weight and density of the specimen corresponding to each mixture

Another important aspect is that the expanded polystyrene has more influence on the density of the specimen than the polyepoxide. This is due to the differences in the physical characteristics among both polymers. For example, the specimen prepared with the mixture 2 (50\% gravel and $50 \%$ expanded polystyrene) attained the average density of $1.75 \mathrm{~g} / \mathrm{cm}^{3}$, which represents a reduction of $35.4 \%$ with respect to the control samples (M1), while the specimen that was prepared with the mixture 5 (50\% gravel and $50 \%$ polyepoxide) attained the average density of $2.35 \mathrm{~g} / \mathrm{cm}^{3}$, representing the reduction of $13.2 \%$ with respect to $\mathrm{M} 1$ density.

It is necessary to mention that the observed result is directly proportional to the amount of aggregate. As can be observed in the specimens of the mixtures M3 and M6, the density reduction difference is $\sim 30 \%$, while in the specimens of the mixtures M4 and M7 the density reduction difference is only $7.7 \%$. By completing the analysis, the specimens of the mixture M11 (100\% polyepoxide particles) got the average density of $1.79 \mathrm{~g} / \mathrm{cm}^{3}$, which represents a reduction in density of $34 \%$ relative to the control sample. Finally, the measured average densities are marked in the eleven types of samples (black dots), as can be seen in Fig. 2.

\subsection{Compressive Strength}

Fig. 3 shows the results of the compressive strength $F^{\prime} c$ of the particulate composite specimens corresponding to each mixture after 28 days (shaded bars). According to the results, the specimens elaborated with the mixture 1 (M1) exhibited the highest compressive strength with the average value of $85.20 \mathrm{~kg} / \mathrm{cm}^{2}$, followed by the specimens of the mixtures M7 and M11 with the values of 81.73 and $76.67 \mathrm{~kg} / \mathrm{cm}^{2}$, respectively. It is important to mention that for three types of evaluated specimens their maximal resistance to compression are higher than the limit value of $70 \mathrm{~kg} / \mathrm{cm}^{2}$ (dash line), established by the Mexican standard (Mexican norm NMX-C-404-ONNCCE-2012). The effect of replacing gravel by the polyepoxide resin in the specimens is clear, the higher content of polyepoxide, the lower value of the compressive strength.

On the other hand, the specimens elaborated with expanded polystyrene registered the lowest values of resistance to compression. The specimens with the lower value of compressive strength were those elaborated with the mixtures M3, M8 and M10 and their measured values were $20.52,17.60$ and $9.32 \mathrm{~kg} / \mathrm{cm}^{2}$, respectively. It is a fact that the expanded polystyrene, by its physical characteristics, reduces the density of the samples, as discussed in the previous section. The use of this polymeric material as aggregate can cause a reduction in density of up to $76 \%$. However, the value of the compressive strength of the samples is also lowered. For comparison, by referring to the specimens with polyepoxide aggregates, the effect of reducing the compressive strength is less critical. This result can be attributed to the physical characteristics of this type of polymer, especially its hardness and rigidity. 


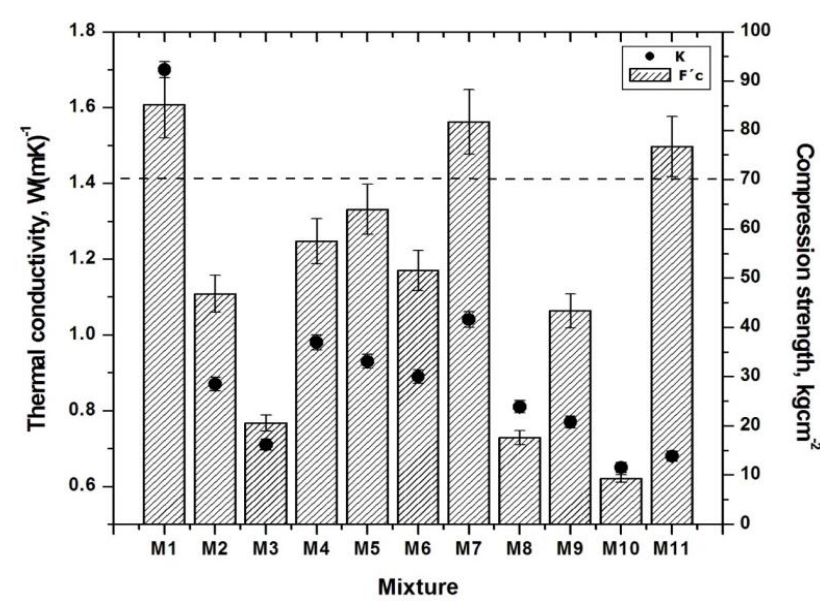

Fig. 3. Compressive strength and thermal conductivity of the specimens after 28 days
In order to verify that the mechanical behavior of the cubic specimen is the same as that of the standard block, simulations were performed by means of the SolidWorks virtual platform [10] (Fig. 4). First, a virtual test of compression was performed on the cubic block. A charge of $1925 \mathrm{~kg}$ on the upper face of the cube was assumed (Fig. 4a). For the test, a safety factor of 1 was established and an elastic limit of $150 \mathrm{~kg} / \mathrm{cm}^{2}$ was considered. By applying Eq. (1), the value of compressive strength of $77 \mathrm{~kg} / \mathrm{cm}^{2}$ was obtained. In the same way, a test of virtual compression on the standard block $(15 \times 20 \times 40 \mathrm{~cm})$ was carried out. The maximum load of $23100 \mathrm{~kg}$ was assumed (Fig. 4b). As in the previous case, by applying Eq. (1), the value of $77 \mathrm{~kg} / \mathrm{cm}^{2}$ for the resistance to compression was obtained. These results justify the use of the cubic specimen (Fig. 1) in the compression test, since the mechanical response of the standard blocks is practically the same.
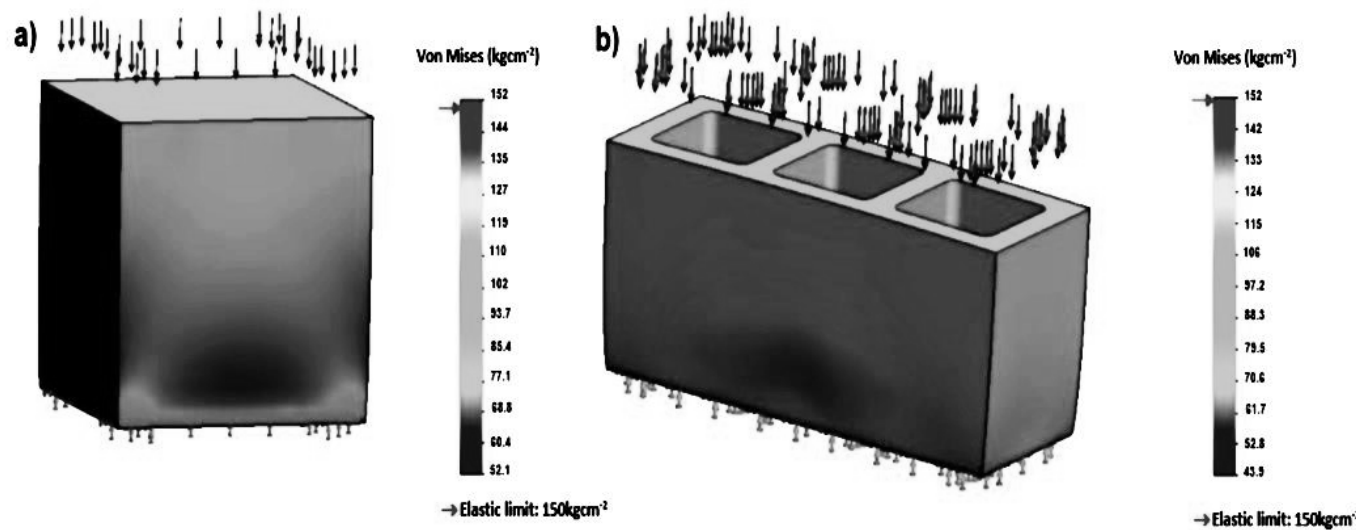

Fig. 4. Image of the blocks used in the Solid Works virtual platform: cubic block of $5 \times 5 \times 5 \mathrm{~cm}$ (a) and standard block of $15 \times 20 \times 40 \mathrm{~cm}$ (b). For simulation uniformly distributed loads on the upper face were assumed

\subsection{Thermal Conductivity}

The results in the determination of the thermal conductivity $K$ of the cubic specimens after 28 days of curing are shown in Fig. (black dots). According to the results, all cubic specimens presented a reduction in the thermal conductivity with regard to the value determined in the mixture M1, which showed a thermal conductivity of $1.70 \mathrm{~W} / \mathrm{mK}$. The thermal conductivity of the specimens that were elaborated with the mixture M10 were lower, approximately $0.65 \mathrm{~W} / \mathrm{mK}$, representing the $62 \%$ reduction of this physical property. Likewise, the specimens elaborated with the mixtures M3 and M11 showed very close values: 0.70 and $0.68 \mathrm{~W} / \mathrm{mK}$, respectively. From the results it is clear that insertion of polymeric particles into the specimens notoriously reduces their thermal conductivity, especially for M3 and M10, which were elaborated with a high content of expanded polystyrene. However, as it has been discussed, due to their low density and poor rigidity the compressive strength of such specimens is reduced.

On the contrary, in the case of specimen elaborated with the mixture M11, besides presenting a reduction in its thermal conductivity, its compressive strength is over the established standard $\left(70 \mathrm{~kg} / \mathrm{cm}^{2}\right)$. Finally, by completing the analysis, the elaborated specimens with the mixtures M4, M5 and M7 showed a reduction in the thermal conductivity less marked than in the above cases, by obtaining values of $0.98,0.93$ and $1.04 \mathrm{~W} / \mathrm{mK}$ respectively. This result can be attributed to the low percentage of polymeric aggregates.

\section{Conclusions}

The analysis of the elaborated specimens with the mixture M11 evidenced that is possible to replace the gravel by polyepoxide particles in the production of 
masonry elements. For this group of samples, the obtained average values of density, compressive strength and thermal conductivity were $1.79 \mathrm{~g} / \mathrm{cm}^{3}, 76.67 \mathrm{~kg} / \mathrm{cm}^{2}$ and $0.68 \mathrm{~W} / \mathrm{mK}$, respectively. In regard to the control specimen (M1), the values of density and thermal conductivity represented the reduction of $\sim 34$ and $60 \%$, respectively. Meanwhile, the compressive strength is higher than the limit established by the Mexican standard $\left(70 \mathrm{~kg} / \mathrm{cm}^{2}\right)$. As for the physical appearance, it is observed that the attained adherence among particles allows a smooth superficial finish without rough areas and free of porosity.

It was observed that the aggregates of expanded polystyrene allowed the elaboration of lightweight specimens with excellent thermal insulation. However, the insertion of these polymeric particles reduced the mechanical resistance to compression. As for the physical appearance of this group, rough areas and presence of porosity were seen on the faces of the specimens, which reflects poor adherence among particles.

Based on the above-mentioned, the use of the polyepoxide as a solid aggregate in the elaboration of building blocks presents an alternative for the construction industry. A great quantity of this type of resin is discarded in diverse factory processes. Therefore, the reuse of this polymeric material would reduce the environmental impact. Moreover, as an aggregate, it would provide a sustainable composite product of low cost, the characteristics of which would allow its application in the construction industry.

\section{Acknowledgements}

Authors thank to National Council of Science and Technology of México (CONACYT) for the financial support (number of support 395196), laboratory of physical tests of construction materials LACONTE, Department of Materials of the Metropolitan Autonomous University, and University of the Mexico State for their support of the laboratory experiments.

\section{References}

[1] Luai M., Ahmad A.: Appl. Thermal Eng., 2008, 29, 1123. https://doi.org/10.1016/j.applthermaleng.2008.06.003

[2] Munive G., Leal A., Pech M. et al.: Mineral Proces. Extract. Metallurg., 2011, 26, 1.

https://doi.org/10.1080/08827508.2011.604696

[3] Pérez J., Cabanillas R., Hinojosa J., Borbón A.: Información Tecnológica, 2011, 223, 27. https://doi.org/10.4067/S071807642011000300005

[4] Vergara E., Vergara D., Najera P., Otaño L.: Proceed. $18^{\text {th }}$ Int. Congress on Project Management and Engineering, España, Alcañiz 2014, 1009.

[5] De Melo A., Silva E.: Materiales de Construcción, 2013, 63, 479. https://doi.org/10.3989/mc.2013.05912

[6] Chabannes M., Charles J., Clerc L., Garcia E.: Construct. Build. Mater., 2014, 70, 428. https://doi.org/10.1016/j.conbuildmat.2014.07.025

[7] González I., González B., Martínez F., Carro D.: Materiales de Construcción, 2016, 66, 1. https://doi.org/10.3989/mc.2016.06415

[8] Askeland D., Pradeep P., Wright W.: Ciencia e Ingeniería de los Materiales. CENGAGE Learning, EUA 2011.

[9] Fitzgeralg R.: Mecánica de materiales. Addision-Wesley Publishing Company Inc., EUA 2000.

[10] Gómez S.: Solid Works Simulation. España Ra-Ma, España 2010 .

Received: August 23, 2018 / Revised: November 21, 2018 /

Accepted: January 31, 2019

\section{АНАЛІЗ МОЖЛИВОСТІ ВИКОРИСТАННЯ ПОЛІМЕРНИХ АГРЕГАТІВ ПРИ ПРОЕКТУВАННІ БУДІВЕЛЬНОГО БЛОКА}

\footnotetext{
Анотація. Виготовлено композитний матеріал 3 порошковим наповнювачем з суміші иементу, гравію та води з додаванням порошку поліепоксиду та/або пінополістиролу. 3 метою ущільнення кожну суміш виливали в прес-форму, залишаючи протягом короткого періоду, після чого видаляли. Для повного затвердіння зразків під час останнього етапу використано воду. За допомогою сертифікованих методів визначено масу, міцність на стиснення $і$ теплопровідність композиту.

Ключові слова: будівельний блок, композитний матеріал з порошковим наповнювачем, міџність на стиснення, теплопровідність, термостабільний полімер.
} 